em que se estabelece a base atómica para a vida!

A publicação de $A$ Origem das Espécies por Charles Darwin em 1859 assume que as propriedades de um organismo são hereditárias e que, de vez, em quando, podem ocorrer alterações. Tal veio despertar a atenção para a natureza e o modo como se efectua essa transmissão de propriedades nos organismos vivos.

O primeiro trabalho que estabelece essa base atómica foi a determinação da estrutura do ADN por James Watson, Francis Crick e Maurice Wilkins, galardoados com o prémio Nobel em 1962. O segundo prémio da trilogia foi atribuído a Roger Kornberg em 2006 pelas estruturas de raios- $X$ que explicam como a informação contida no ADN é copiada para a molécula de ARN mensageiro.
O prémio de 2009 é atribuído pelo esclarecimento do modo como a informação genética se converte em acção.

Sabia-se já desde os anos de 1960 que a informação genética codificada no ADN é copiada para o ARN mensageiro que, formado no núcleo da célula, se move para o seu exterior, o citoplasma, onde é captado pelo ribossoma que usa essa informação para produzir proteínas.

Após um trabalho iniciado nos finais de 1970 por Ada Yonath sobre a utilização de difracção de raios-X para determinar a estrutura do ribossoma (que existe em todos os organismos vivos), só no final do anos de 1990 e princípios deste século, foi possível determinar estruturas cristalinas que mostram as posições atómicas de subunidades no ribossoma.
Este trabalho, que contou com a contribuição determinante dos três laureados, permitiu assim perceber como a informação codificada com as quatro bases do ADN se transforma em vida!

Estes três cientistas mostraram também como diferentes antibióticos se ligam ao ribossoma e de que forma bloqueiam o processo de conversão da informação em proteínas.

Os resultados deste trabalho podem assim ser usados na pesquisa de novos antibióticos. E esta consequência é talvez mais importante do que o esclarecimento, em si, da estrutura do ribossoma.

(Adaptado dos Press Release, em www.nobelprize.org)

JM

\title{
8a Conferência de Química Inorgânica da SPQ
}

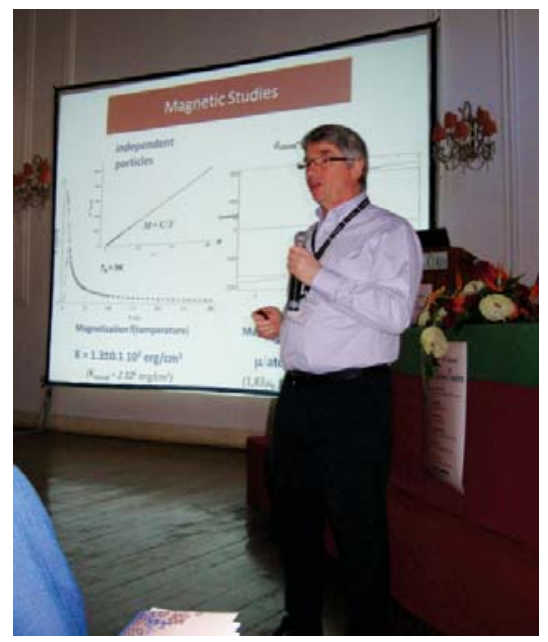

Realizou-se, nos passados dias 16 e 17 de Outubro na Curia, a $8^{a}$ Conferência de Química Inorgânica. Dando continuidade aos encontros bianuais desta Divisão da SPQ, e recuperando os designados "no meio" como "Bairrada Meetings", a conferência deste ano reuniu cerca de 170 participantes, num local agradável e com um óptimo tempo de verão ainda persistente.

A Comissão Organizadora, coordenada pelo Presidente da Divisão de Química Inorgânica, o Prof. Tito Trindade da Universidade de Aveiro, reuniu um conjunto de 6 conferencistas convidados que abordaram vários temas desta área e que ilustram a sua transversalidade:

- Bruno Chaudret (Prémio Sir Geoffrey Wilkinson 2009), do CNRS de Toulouse (França), que abriu a Conferência com a palestra "Synthesis, shape control and organization of magnetic nanoparticles" em que abordou a aplicação de compostos organometálicos na síntese de nanomateriais magnéticos;

- João Rocha, da Universidade de Aveiro, que centrou a sua apresentação nos materiais híbridos funcionais ("Multi-functional inorganic-organic hybrid materials");

- Joaquim Faria da Faculdade de Engenharia da Universidade do Porto que desenvolveu o tema da fotocatálise com base no dióxido de titânio e seus compósitos com nanotubos de carbono, com especial enfoque nas aplicações para purificação de água e do ar ("New materials for photocatalytic applications");

- Joaquim Marçalo, do Instituto Tecnológico e Nuclear (Sacavém) que abordou a química de elementos do bloco $f$ ("Inorganic Chemistry without solvent or lattice: gas-phase studies of the $f$ -block elements");

- Olga Iranzo, do ITQB, que apresentou uma palestra sobre o design de peptídeos funcionais capazes de coordenar catiões metálicos e de promover a formação de estruturas ordenadas em solução ("Designed peptides: highly versatile ligands for metal coordination"), podendo ser usados como sensores, e,

- Tamás Kiss, da Universidade de Szeged, Hungria, cuja apresentação, "Metal ion chelators in the therapy for Alzheimer's disease", abordou a síntese de moléculas capazes de actuarem como agentes quelantes em relação a catiões metálicos (Cu(II) e Zn(II)), que parecem desempenhar um papel importante na doença de Alzheimer, dado que promovem a formação de precipitados de amilóide.

Foram ainda apresentadas 18 comunicações orais seleccionadas que abordaram a síntese de compostos inorgânicos de natureza diversa, sua caracterização estrutural, óptica e magnética, e aplicações. As 133 comunicações em poster foram distribuídas por duas sessões, uma em 
cada dia, promovendo animadas discussões, muitas delas apresentadas por estudantes o que permite antever uma sustentada passagem de testemunho nesta área. É de referir a significativa assistência que em média esteve presente durante a apresentação das comunicações, contribuindo para interessantes e por vezes animadas discussões.

No final da conferência teve lugar a reunião da Divisão de Química Inorgânica que elegeu o novo presidente, a Prof ${ }^{a}$ Ana Margarida Martins, do Instituto Superior Técnico, que assumiu, assim, a responsabilidade de organizar o próximo encontro.

Nesta reunião foi ainda aprovado o regulamento do prémio Alberto Romão Dias.

\section{Actualidades Científicas}

\section{VIsUalizAÇÃo de Átomos e Ligações DE Moléculas}

Através da funcionalização da ponta de um microscópio de força atómica, o investigador Leo Gross e seus colaboradores da IBM Research, em Rüschlikon, Suíça, conseguiram aumentar significativamente a resolução da microscopia de força atómica (AFM), tornando possível visualizar a estrutura completa da molécula pentaceno (Science 325 (2009) 1110).

Embora tenha sido possível anteriormente por AFM visualizar átomos individuais em nanotubos e em células unitárias de cristais em superfícies, esta é a primeira vez que as posições de todos os átomos e ligações de uma molécula, incluindo os hidrogénios, foram visualizadas com precisão de escala atómica. A equipa da IBM ultrapassou a barreira da resolução atómica testando uma variedade de átomos e moléculas como terminação da ponta AFM, tendo conseguido os melhores resultados ao incorporar monóxido de carbono.

As distâncias entre os átomos de pentaceno são de apenas $1,4 \AA$, e as novas imagens conseguidas são, segundo Gross, "o estado-da-arte em termos de resolução lateral". Nas imagens, é possível deduzir as posições dos átomos de hidrogénio, que são demasiado pequenos para ter sido possível a sua visualização anterior.

O estudo "é um avanço significativo no campo da microscopia e na caracterização de moléculas em superfícies", diz Óscar Custance do National Insti- tute for Materials Science, em Tsukuba, Japão. O físico Alexander Shluger da University College London salienta que o estudo "é um passo muito importante e terá fortes implicações no nosso conhecimento sobre adsorção de moléculas em superfícies".

"Esperamos conseguir visualizar muitas moléculas com resolução atómica", diz Gross. Entre questões pendentes estão as seguintes:

"Será possível diferenciar entre carbono, enxofre, azoto e outros átomos?

Será possível determinar o número de electrões que existem em cada ligação?".

(adaptado de Chemical \& Engineering News 87 (35) (2009) 6)

Helder Gomes

\section{NANOCRISTAIS Ao QUILO!}

De acordo com investigadores da Coreia do Sul, é possível sintetizar nanocristais com um tamanho uniforme por um procedimento simples e em grande quantidade (na escala do quilograma).

A existência de um método de baixo custo para produzir grandes quantidades de nanocristais monodispersos (de tamanho único) pode acelerar o desenvolvimento de aplicações de nanotecnologia.

Existem vários métodos para a preparação de nanocristais monodispersos, mas, tipicamente, esses métodos apenas permitem produzir algumas gramas de produto e necessitam de passos de selecção de tamanhos.

Taeghwan Hyeon, um professor de Engenharia Química da Universidade Nacional de Seul, comunicou que o seu grupo de investigação, em colaboração com Wan-Jae Myeong e colaboradores da empresa Hanwha Chemical, também de Seul, desenvolveu um processo que permite sintetizar cristais de magnetite $\left(\mathrm{Fe}_{3} \mathrm{O}_{4}\right)$ com um diâmetro uniforme de $11 \mathrm{~nm}$ em quantidade por lote na escala do quilograma.

O método, que tem uma duração inferior a sete horas para obter o produto final e que não exige passos de selecção de tamanhos, envolve a reac- ção de um surfactante com cloreto de ferro hidratado, um reagente barato, seguida de um aquecimento lento do complexo formado num solvente com ponto de ebulição elevado.

O aumento de escala na síntese deste tipo de nanocristais poderá ser particularmente útil em aplicações de armazenamento de dados, imagiologia médica e sistemas de libertação de fármacos por processos magnéticos.

(adaptado de Chemical \& Engineering News 87 (34) (2009) 33)

Helder Gomes 